\title{
Raising Legal Age of Marriage for Women: The Law, The Reasons and The Criticism
}

\section{K Suresh*}

Public Health Consultant, Bengaluru and Visiting Professor - MPH, KSRDPRU,

Gadag, India

*Corresponding Author: K Suresh, Public Health Consultant, Bengaluru and

Visiting Professor - MPH, KSRDPRU, Gadag, India.
Received: January 06, 2022

Published: January 31, 2022

(C) All rights are reserved by K Suresh.

\section{Abstract}

The Prohibition of Child Marriage (Amendment) Bill, 2021, which was introduced in Lok Sabha on 21 December 2021, seeks to increase the minimum age of marriage of females to 21 years from the current 18 years, to bring parity in the age of marriage for both men and women in the country.

Marriage is an instrument of social control, but often become a route of escape from conservative shackles for many women in rural India. No girl below the age of 18 can be considered to have given consent to sex, according to the existing law. Raising the age of marriage and age of consent have both been considered as progressive measures to favour women, for historical reasons in India.

The law prescribes a minimum age of marriage to essentially outlaw child marriages and prevent the abuse of minors. Personal laws of various religions have their own standards, often reflecting respective customs. For Hindus, The Hindu Marriage Act, 1955 sets 18 years as the minimum age for the bride and 21 years as the minimum age for the groom. In Islam, the marriage of any girl who has attained puberty is considered valid. The Special Marriage Act, 1954 and the Prohibition of Child Marriage Act, 2006 also prescribe 18 and 21 years as the minimum age of consent for marriage for women and men, respectively. According to the draft Bill, the proposed law will apply to all communities and once enacted, will supersede existing marriage and personal laws.

India would, however, be amongst the few countries globally where the legal age of marriage for women would be 21 . In neighbouring China, it is 20 , while in countries like the UK and US, it is 18 but with exceptions and variations.

For the new era of avoiding gender discrimination, in all social and economic participation the laws are to be amended and implemented. The current government has decided to propose an increase in the age for marriage for girls from 18 to 21 as for boys. The reasons put forth include i) gender-neutrality, ii) poor nutritional levels of mothers and their children following early marriages, iii) their overall health and mental wellbeing iv) other population and health reasons include high Infant Mortality Rate and Maternal Mortality Rate among teen age pregnancies v) Socio-economic reasons of empowerment of women who are denied access to education and livelihood after an early marriage.

People resisting this amendment quote autonomy as the concerns of implementing the law. Their plea is if women are considered adults at 18 for voting, why not for marriage decisions as well?" Some advocate achieving gender parity by making 18 the age for marriage for all genders. For them the government move is an attempt to replace all religious civil codes by a uniform civil code.

However, the rationality in increasing the marriage age for women without spelling out plans to improve health and education is a puzzle, but can be addressed which might be detailed once the law is passed.

Materials and Methods: The draft bill, committee recommendations, Various media coverage and debates across the country on the issue.

Keywords: Age at Marriage for Women; Existing Divergent Marriage Laws; Uniform Civil Codes; Equity and Parity; Gender Discrimination; NFHS 5 and 4 


\section{Introduction}

The Prohibition of Child Marriage (Amendment) Bill, 2021, which was introduced in Lok Sabha on 21 December 2021, seeks to increase the minimum age of marriage of females to 21 years from the current 18 years, to bring parity in the age of marriage for both men and women in the country [1].

The law prescribes a minimum age of marriage to essentially outlaw child marriages and prevent the abuse of minors. Personal laws of various religions have their own standards, often reflecting respective customs. For Hindus, The Hindu Marriage Act, 1955 sets 18 years as the minimum age for the bride and 21 years as the minimum age for the groom. In Islam, the marriage of any girl who has attained puberty is considered valid. The Special Marriage Act, 1954 and the Prohibition of Child Marriage Act, 2006 also prescribe 18 and 21 years as the minimum age of consent for marriage for women and men, respectively [2].

For the new era of avoiding gender discrimination, in all social and economic participation the laws are to be amended and implemented [3]. The current government has decided to propose an increase in the age for marriage for girls from 18 to 21 as for boys. The reasons put forth include i) gender-neutrality, ii) poor nutritional levels of mothers and their children following early marriages, iii) their overall health and mental wellbeing iv) other population and health reasons include high Neonatal, Infant and Maternal Mortality Rates among teen age pregnancies v) Socio-economic reasons of empowerment of women who are denied access to education and livelihood after an early marriage.

\section{Current Status of age at marriage}

The recently released National Family Health Survey (NFHS v 2019-20) revealed that child marriage has come down marginally from $27 \%$ in $2015-16$ to 23 per cent in $2019-20$ in the country, though the government is ambitious of pushing it further down [4]. While NFHS data showed improvement in participation of women in household decisions, working for cash, having bank account, or owning and using own mobile phone when compared to NFHS 4 (2015-16), owning a house or land has gone down. Similarly, average out of pocket expenditure for delivery has reduced from 8518 to 2548 that indicates Government's effort in improving institutional deliveries. While reduction in sub-normal BMI from $15 \%$ to $10 \%$ is encouraging the fact that overweight and obesity has gone up from $33.5 \%$ to $41 \%$ is matter of concern.
The process and committee's recommendations

The committee has recommended the age of marriage be increased to 21 years, based on feedback they received from young adults from 16 universities and reached out to young adults in far-flung areas and marginalised communities reached through NGOs. Majority of the youth belonging to all religions, from rural and urban areas equally opined in favour of raising the age making it equal to both women and men at 21 years. In addition, the committee recommends sex education, Skill and business training in schools and undergraduate courses in colleges The committee has also alerted the government to ensure these facilities are implemented and women are empowered, to make the law effective. The committee has recommended to mount awareness campaign on a massive scale to encourage social acceptance of the new legislation, far more effective adoption of the law. However, some antagonists including child and women's rights activists, and family planning experts are not in favour of increasing the age of marriage for women by a legislation. They fear it would push a large portion of the population into illegal marriages. Their argument is that despite the legal age of marriage at 18 years, child marriages continue and a decrease in such marriages is because of increase in girl's education and employment opportunities and not by law alone. They feel that the law may negatively impact the remote rural population and Scheduled Caste and Scheduled Tribes, making them lawbreakers.

\section{Discussions}

The Prohibition of Child Marriage (Amendment) Bill, 2021, which was introduced in Lok Sabha on December 21, seeks to increase the minimum age of marriage of females to 21 years from the current 18 years. Representatives of minority communities have raised concerns on how the change will affect personal laws in the country. According to the draft Bill, the proposed law will apply to all communities and once enacted, will supersede existing marriage and personal laws [1].

It is no secret that women lag men on almost all parameters, and many continue to be married even before they reach the age of 18. The Covid 19 pandemic has aggravated many of these problems. Raising the legal age of weddings is an indirect attempt to address other gender inequalities. It is imperative to tackle gender inequality and gender discrimination and to put in place adequate measures to secure health, welfare and empowerment of our women and girls and to ensure status and opportunity for them at par 
with men", says the Bill, which now has been referred to the Parliamentary Standing Committee.

The National Family Health Survey v (2019-20) found that 23.3 $\%$ of women in the age group of 20 to 24 years were married before they turned 18 and about $6.8 \%$ of women in the age group of 15-19 years were already mothers or pregnant at the time of the survey.
Only $41 \%$ of them have had more than ten years of schooling as against $50.2 \%$ of men. Socio-economic empowerment as measured by owning a mobile phone, was just $54 \%$ of women (urban $69.4 \%$ and rural-46.6\%) as against nearly $75 \%$ of men (Urban $90 \%$ and rural 70\%). The lower participation of women in the workforce and wages are also partly attributable to lack of education, marriage, and domestic responsibilities [4].

Women's (15-49) empowerment Indices NFHS-5
\begin{tabular}{|l|l|l|l|}
\hline \multicolumn{3}{|l|}{ EXCERPTS FROM NFHS SURVEY- WOMEN'S EMPOWERMENT (women aged 15-49) } \\
\hline SI. No & Particulars & $2020-21$ & $2015-16$ \\
\hline 1 & Participation of married women in household decisions & $92 \%$ & $73.8 \%$ \\
\hline 2 & Women who worked in last 12 months and paid cash & $24.9 \%$ & $21.1 \%$ \\
\hline 3 & Women owning a house and/or land (alone or jointly) & $22.7 \%$ & $34.9 \%$ \\
\hline 4 & Women having bank or savings account that they use & $72.5 \%$ & $64.5 \%$ \\
\hline 5 & Women having mobile phone that they themselves use & $73.8 \%$ & $66.6 \%$ \\
\hline
\end{tabular}

Figure 1

\section{Women and children and labour market}

The economic lens and the urban scenario now confirm that the women participation in the labour market as the best way of empowering them. With a rise in the age at marriage they may be able to participate in the labour market before marriage; and to continue to work even after marriage, that will reduce the fertility rate. It also gives them greater bargaining power to deal with social evils like dowry. Increased participation of women in the labour market has a tremendous positive effect on the nutritional status of mother and children, child rearing and caring practices leading to improve general health, understanding of primary prevention activities likes balanced diet, personal hygiene, menstrual hygiene, immunization, physical activities, that would influence cardiac and mental wellbeing and economic wellbeing of the entire household [5].

"Raising the legal age of marriage can address other gender inequalities, such as girls being pulled out of school for marriage; the health risks from pregnancies, including maternal mortality and neonatal mortalities following early marriage entails. Most importantly the unpreparedness of girls in bringing up children if they are themselves are not fully developed physically and mentally.

A recent school and community-based baseline nutritional survey of $1-8^{\text {th }}$ standard government schools in the districts of Yadgir and Gadag, Karnataka indicate that children over the age of
10 years, miss about 30-50 days of schooling every year during agricultural seasons like sowing, harvesting, cotton plucking etc. as they work, earn INR 100-150 for half a day, and contribute to income of the household. It was heartening to note that in class 8 the number of boys and girls was equal, but in class 10 the girls dropped to $30-40 \%$ of the total strength especially in rural schools. A discussion with department of public instruction stakeholder and parents fee that flexi timing in the rural schools during seasonal agricultural work may be beneficial for both parties. Instead of 5-6 hours of schooling daily, during seasons late evening schools for 3 hours may be more beneficial. The number of such hours lost can be compensated in non-seasonal and holidays.

Of course, the Government may have to provide financial incentives for girls to remain in school, including scholarships; increasing the range and number of jobs educated girls can get; and making it safer and easier for girls to attend college or work in small towns and cities through safe transport and hostel facilities. The effect of such facilitation is seen remote urban colleges and universities like Karnataka State Rural development and Panchayat Raj University (KSRDPRU), Gadag 582101, where girls outnumber in the Post graduate scholars in courses like MPH, MSW, M.Sc. (Food science Technology) et, as the turion fee is less than INR 20,000 per year, hostel facilities and scholarships and fee concessions encourage girls from neighbouring 6-8 districts. 
Research also shows that parents are more likely to let girls finish school and delay marriage if they have good job prospects close to home. This will raise the girl's age of marriage without the pressure of legal measures.

The marriage bill has been sent to a parliamentary committee, but another controversial piece of legislation that was passed makes changes to the law relating to elections. It amends both The Representation of the People Acts of 1950 and 1951. Ironically, the election law amendment reinforces the voting rights of 18-yearolds. "The Bill also increases the number of qualifying dates for the revision of electoral rolls from one per year to four. At present, January 1 of each year is the qualifying date. Every year, those turning 18 on or before that day is eligible to be a voter. This has been amended to include April 1, July 1, and October 1 so that one need not wait for the end of the year to apply for inclusion.

We already have in Tamil Nadu's welfare schemes that have been incentivising, for decades, marriages wherein women are above 18. Under 5 different Marriage Assistance Schemes, the State government provides a cash assistance of Rs 25,000 launched between 1967 and 1989. Similarly, to promote education among women, TN government, increased the assistance to Rs 50,000 (for women graduates or diploma-holders) in 2011. The minimum age for availing the benefit is 18 years and for graduates and diplomaholders, it is 20 . Another scheme of a woman graduating from a poor family is eligible for eight grams of gold and Rs 50,000 for her marriage. The number of applications received from graduates has increased substantially in the last few years [6].

A review of the age at marriage NFHS V (2091-20) by states indicates that women who were married before the age of 18 years range from 6.3 in Kerala to $42.5 \%$ in Bihar and $41.6 \%$ in the States of West Bengal headed by a women chief minister. While all India average indicates that $23.3 \%$ of women and $17.7 \%$ men were married before the prescribed age for them, the change of only $3.5 \%$ among women and $2.7 \%$ among men over a period of 5 years is not encouraging. The southern states show that they not only have rates lower than national average but also have been able to reduce these rates much more between the two surveys over a period of 5 years. Tamil Nadu has made the biggest reduction of about $21.5 \%$ over the five years attributable to their marriage assistance schemes [3].

\begin{tabular}{|c|c|c|c|c|c|}
\hline & \multicolumn{2}{|c|}{ NFHS 5 (2019-21) } & \multicolumn{3}{|c|}{ NFHS 4 (15-16) } \\
\hline & $\mathbf{U}$ & $\mathbf{R}$ & $\mathbf{T}$ & $\mathbf{T}$ & \\
\hline Women $20-24$ yrs. married $<18$ years $(\%)$ & 14.7 & 27.0 & 23.3 & 26.8 & India \\
\hline Men 25-29 yrs. married < 21 years (\%) & 11.3 & 21.1 & 17.7 & 20.3 & \\
\hline Women $20-24$ yrs. married < 18 years $(\%)$ & 10.4 & 15.2 & 12.8 & 16.3 & $\mathrm{TN}$ \\
\hline Men $25-29$ yrs. married $<21$ years $(\%)$ & 6.0 & 3.3 & 4.5 & 9.0 & \\
\hline Women $20-24$ yrs. married < 18 years $(\%)$ & 15.7 & 27.6 & 21.9 & 26.3 & Maharashtra \\
\hline Men 25-29 yrs. married < 21 years (\%) & 9.6 & 11.3 & 10.5 & 11.4 & \\
\hline Women 20.24 yrs. married < 18 years $(\%)$ & 16.1 & 24.7 & 21.3 & 21.4 & KAR \\
\hline Men 25-29 yrs. married < 21 years (\%) & 4.5 & 7.2 & 6.1 & 9.1 & \\
\hline Women $20-24$ yrs. married < 18 years $(\%)$ & 4.1 & 8.2 & 6.3 & 7.6 & KER \\
\hline Men 25-29 yrs. married < 21 years (\%) & 0.0 & 2.5 & 1.4 & 2.8 & \\
\hline Women $20-24$ yrs. married < 18 years $(\%)$ & 9.6 & 17.9 & 15.8 & 21.1 & UP \\
\hline Men 25-29 yrs. married < 21 years (\%) & 17.1 & 25.4 & 23.0 & 28.7 & \\
\hline Women $20-24$ yrs. married < 18 years $(\%)$ & 27.9 & 43.4 & 40.8 & 42.5 & Bihar \\
\hline Men 25-29 yrs. married < 21 years $(\%)$ & 18.3 & 34.3 & 30.5 & 35.3 & \\
\hline Women $20-24$ yrs. married < 18 years $(\%)$ & 13.0 & 26.6 & 23.1 & 32.4 & MP \\
\hline Men 25-29 yrs. married < 21 years $(\%)$ & 15.8 & 35.1 & 30.1 & 31.2 & \\
\hline Women $20-24$ yrs. married < 18 years $(\%)$ & 8.8 & 8.7 & 8.7 & 7.6 & Punjab \\
\hline Men 25-29 yrs. married < 21 years $(\%)$ & 10.9 & 11.7 & 11.4 & 11.1 & \\
\hline Women $20-24$ yrs. married $<18$ years $(\%)$ & 26.2 & 48.1 & 41.6 & 41.6 & West Bengal \\
\hline Men $25-29$ yrs. married $<21$ years $(\%)$ & 8.4 & 25.3 & 20.0 & 17.3 & \\
\hline
\end{tabular}

Table 1: Women 20-24 years and Men 25-29 years married before the respective permissible age. 
Maharashtra has these figures between 22-26\% in both surveys, but the decrease between NFHS 4 and NFHS 5 has been $15.6 \%$. Karnataka has reduced by only $0.1 \%$ points over the 2 surveys. Northern states like MP, UP, and Bihar have reduced the proportion of women marrying before 18 years by a tune of $28.7 \%, 25 \%, 4 \%$. West Bengal has remained at a high level of $41.6 \%$ over the last 5 years.

The states in each regions have an example of state performing better compared to the neighbouring states. For example, Bihar can emulate MP or UP implementation strategies. Kerala and TN strategies can be trend setters for Karnataka, Maharashtra, Wes Bengal, AP, and Telangana.

While the median age of marriage for women in India between the ages of 25 to 49 years, in 2015-16 (NFHS IV) was 19.8 in urban areas and 18.1 in rural areas. The lowest median age for women among Hindus was 18.5 followed closely by Muslims at 18.6 years, Buddhists is 19.2, Sikhs 20.9, Jains 21.2, and Christians 21.6.

A recent debate on Time of India, Bengaluru had public opinion polled in favour of raising marriage age for women to the tune of $66.7 \%$ before the debate that increased to $77.5 \%$ after the debate, clearly indicating more 3/4 majority are in favour. The reasons in favour include 1) differential age at marriage is the biggest discriminatory law 2) By 21 women would be more physically and mentally and emotionally mature to shoulder the family responsibilities 3) Both should have equal opportunities for marriage and career by the time of the marriage 4 ) raising marriage age will help in attaining better health, family planning and population control. 5) The act will reduce school dropouts and promote financial independence among women. 6) It will also be tool to address patriarchal mindsets.

A few arguing against the raise feel government should not dictate one should or should not marry, after defining 18-year-olds as adults, which is in line with many other countries. Some of them argue that girls will continue to get married younger and hide it and it is also possible that the new law may be misused to harass these communities, and young people. A few also argue that it is not just about personal laws, but also looking at what benefits women. The biggest requirement in India is the safety and security of women. If a girl is at home, her safety becomes the responsibility of the parents, that is why she is often married off early. When women and men are given the right to vote at 18 years, they can take any decision independently when they reach adulthood. How can the Government stop them from getting married?

Of course, the Government must investigate and address these concerns before the Bill becomes law.

\section{Conclusion}

- Marriage is an instrument of social control, but often becomes a route of escape from conservative shackles for many women in rural India and

- Personal laws of various religions reflect respective customs and have their own standards.

- The Special Marriage Act, 1954 and the Prohibition of Child Marriage Act, 2006 prescribe 18 and 21 years as the minimum age of consent for marriage for women and men, respectively.

- The Prohibition of Child Marriage (Amendment) Bill, 2021, introduced in Lok Sabha on 21 December 2021, seeks to increase the minimum age of marriage of females to 21 years from 18 years, to bring parity in the age of marriage for both men and women in the country.

- While medical fraternity and the government is in favour, some antagonists want to increase in girl's education and employment opportunities along with the law. They feel that the law may negatively impact the remote rural population and SC and ST, making them lawbreakers.

- NFHS 2019-21 data suggests sluggish reduction in the proportion of women of 20-24 getting married before 18 years, especially in Bihar, West Bengal, and Karnataka.

- $\quad$ The proposal to increase age from 18 to 21 for women has got favourable opinion poll of more than $2 / 3$ of population.

\section{Bibliography}

1. Ambika Pandit. "Legal Age of Marriage in India: Govt works to raise legal age of marriage for women to 21". Updated: Dec 17, (2021).

2. Bill to raise minimum age of marriage for women to 21 (2021).

3. Shireen Jejeebhoy. "Should India raise the minimum age of marriage?".

4. Women Related Data: NFHS 5 (2021). 
5. Farzana Afridi., et al. "Female Labour Force Participation and Child Education in India: The Effect of the National Rural Employment Guarantee Scheme" (2012).

6. “Centre's wake-up call on women's marriage age comes decades after TN's”.

\section{Assets from publication with us}

- Prompt Acknowledgement after receiving the article

- Thorough Double blinded peer review

- Rapid Publication

- Issue of Publication Certificate

- High visibility of your Published work

Website: www.actascientific.com/

Submit Article: www.actascientific.com/submission.php

Email us: editor@actascientific.com

Contact us: +919182824667 